\title{
Student Loyalty Toward Master's Degree Business Administration Curriculum At Srinakharinwirot University
}

Nak Gulid, Ph.D., Srinakharinwirot University, Thailand

\begin{abstract}
This research aims to study mixed factors of service marketing affecting student loyalty toward the business administration curriculum at the master's degree level at Srinakharinwirot University. It also examines the relationship between student satisfaction and loyalty in the MBA program. The results show that service marketing mixed factors have influenced student satisfaction in the MBA curriculum by approximately 39.4 percent. The product and service aspect is the most important factor in predicting student satisfaction. Furthermore, the service marketing mix has influenced student attitudinal loyalty toward the MBA curriculum by about 26.7 percent, while the servicemarketing mix has influenced student behavioral loyalty by nearly 40.5 percent. Student satisfaction has rather a low positive relation to attitudinal loyalty at the 0.01 level of statistical significance. Student satisfaction has a moderately positive relation to behavioral loyalty at the statistical significance level of 0.01 .
\end{abstract}

Keywords: service marketing mix; attitudinal loyalty; behavioral loyalty; Srinakharinwirot University

\section{INTRODUCTION}<smiles>[C]1C=CCCC1</smiles>

rinakharinwirot university was founded in 1974. One year later, the Social Science Faculty was established. It is comprised of, among others, the departments of Business Administration, Economics, History, and Political Science. In 1999, the Business Administration Department offered the Master of Business Administration program in two areas, marketing and management. Furthermore, the program is divided into three different programs including the regular program, the young executive program and the executive program. In the regular program, students study only on weekdays, whereas in the young executive and executive programs, students study on weekends. The difference between the young executive and executive programs is that students in the young executive program have at least two years of work experience, while students in the executive program have a minimum of five years experience and must attend a special short lecture program and participate in a field trip abroad. In 2010, the number of MBA students in all programs was 341 (graduate school, Srinakharinwirot University, 2010). By university regulation, every faculty has to review and revise its curriculum every 5 years. The year 2010 was the appointed time for developing the curriculum. Thus, the study of the demand side, especially student satisfaction and loyalty, was a necessary stage in developing new curricula. As indicated above, this research attempted to study student satisfaction and loyalty, which are the most important data for developing the new curriculum. Hence, quantitative analysis was employed in this study to capture the important factors influencing student satisfaction and loyalty, both of which provide crucial data to develop the curriculum in the MBA program.

The research objectives of this study are:

1. To study the impact of independent variables (service marketing mix including product and service, price, place, promotion, people, physical evidence, and process) on the dependent variables (satisfaction and loyalty).

2. To study the relationship between satisfaction and loyalty. 


\section{LITERATURE REVIEW}

\section{Service Marketing Mix}

The marketing mix model and theory of parameters was introduced by Rasmussen in 1955, developed by McCarthy in 1960, and further expanded by Kotler in 1967. The marketing mix model grew out of economic theory and also embedded some of its key assumptions into the marketing analysis tool (Hakansson \& Waluszewski, 2005, p. 111). It is a combination of marketing activities that an organization engages in so as to best meet the needs of its targeted market.

Traditional marketing mix was defined by the four Ps (product, price, place, and promotion). In the service sector, the marketing mix includes three additional Ps, which are people, physical evidence, and process (Kotler, 2003). From a managerial standpoint, the relationship between the marketing mix and brand loyalty is extremely relevant. It is important to conduct an investigation to understand whether and how the marketing mix variables are related to the loyalty measure that is used regularly in actual practice (Bhattacharya et al. 1996). In addition, the marketing literature has identified several factors that influence satisfaction, such as location, price, promotion, people, and physical attributes (Woodside and Trappey, 1992; Williams et al., 1978; Urbany et al. 2000; Magi 2003; Babin and Darden, 1996). The aforementioned statements imply that service marketing mix (7Ps) has a strong impact on satisfaction and loyalty.

\section{Satisfaction}

For the past four decades, satisfaction has been one of the most important theoretical and practical issues for most marketers and customer researchers (Jamal, 2004). In this study, the effects experienced during the acquisition and consumption of service have a significant influence on satisfaction judgments (Homburg, et al., 2006). Customer satisfaction is a key element in the marketing process because it contributes to the success of service providers (Darian et al., 2001). In addition, satisfaction is one of the essential factors to predict customer behavior and purchase repetition. Many related empirical studies concluded that satisfied consumers demonstrate loyal behavior (Henning-Thurau et al. 2002; Wong and Zhou 2006). Hence, consumer satisfaction leads to consumer loyalty.

\section{Loyalty}

Building and maintaining customer loyalty lies at the heart of marketing. Loyalty is widely accepted and measured in terms of both attitude and behavior (Jacoby and Kyner, 1973; Jacoby, Chestnut et al., 1978; Dick and Basu, 1994). Chaudhuri and Holbrook (2001) state that brand loyalty is described by two different aspects: behavioral and attitudinal. Behavioral loyalty is defined as repeated purchases of the brand, whereas attitudinal loyalty consists of a degree of dispositional commitment in terms of some unique value associated with the brand. Several studies state that customer satisfaction leads to buying intention or loyalty (Fornell, 1992; Cronin and Taylor, 1992, Wong and Zhou, 2006).

\section{CONCEPTUAL FRAMEWORK}

Independent Variable

$\underline{\text { Dependent Variables }}$

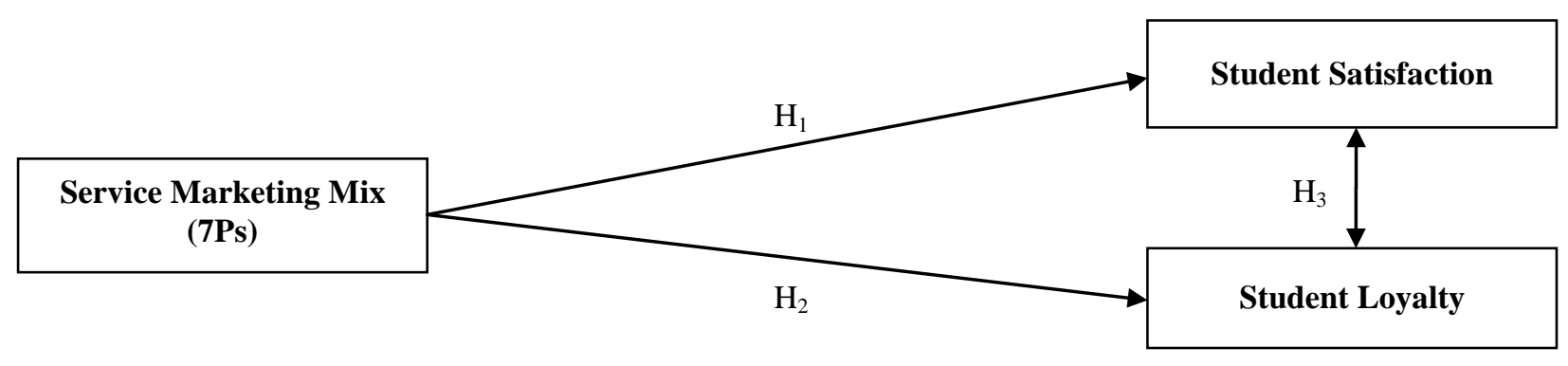




\section{HYPOTHESES}

This section provides the set of hypotheses for testing the determinant of student satisfaction and student loyalty, as follows:

$\mathbf{H}_{\mathbf{1}}$ : $\quad$ Service marketing mix has influenced student satisfaction.

$\mathbf{H}_{2}$ : $\quad$ Service marketing mix has influenced student loyalty.

$\mathbf{H}_{3}$ : $\quad$ There is a positive relationship between student satisfaction and student loyalty.

\section{RESEARCH METHODOLOGY}

\section{Population}

The population included students who studied in the MBA program at Srinakharinwirot University during the 2010 academic year. The total number of students was 341 (graduate school, Srinakharinwirot University, 2010).

\section{Sample Size}

The sample size is calculated by using the known population formula, which is:

$$
\begin{aligned}
\mathrm{n} & =\frac{\mathrm{N}}{1+\mathrm{N}(\mathrm{e})^{2}} \\
& =184
\end{aligned}
$$

In this study, we increased the amount of the sample by $10 \%$; therefore, the total sample size was 202 students. Proportional stratified sampling and convenience sampling were employed for sampling methodology.

\section{Measures}

All measurement items of each construct and its Cronbach alpha level are summarized in Table 1. All measures achieved Cronbach alpha level beyond the recommended level of 0.70, passing the minimum requirement (Nunnally, 1978).

Table 1: Reliability of Measures Used in the Current Study

\begin{tabular}{|l|c|}
\hline \multicolumn{1}{|c|}{ Scales Items } & Cronbach's Alpha \\
\hline Service Marketing Mix, 7 dimensions with 27-item scale on a five-point Likert scale & .7447 \\
\hline - product and service & .8283 \\
\hline - price & .7253 \\
\hline - place & .7969 \\
\hline - promotion & .9036 \\
\hline - people & .8631 \\
\hline - physical evidence & .8545 \\
\hline - process & .8298 \\
\hline Satisfaction, 3-item scale on a five-point Semantic differential scale & \\
\hline Loyalty, 2 dimensions with 9-item scale on a five-point Likert scale & .7265 \\
\hline - attitudinal loyalty & .8678 \\
\hline - behavioral loyalty & \\
\hline
\end{tabular}




\section{FINDINGS}

\section{Respondent profile}

202 students in the MBA program were interviewed for quantitative analysis. The results of all respondents showed that the majority of students were female (70.8\%), and 59.9\% of that group were between 23-28 years old. Most were single (91.6\%). A number of them were employed in the private sector (73.8\%) and 32.2\% earned monthly income that was between THB10,000-19,999 (about USD330-660). Many had studied in the young executive program (59.9\%), while 52\% were marketing majors and had studied in the second year (59.9\%). All details are included in the following table:

Table 2: Respondent Profile of Students

\begin{tabular}{|c|c|c|}
\hline Demographic Profile & Frequency & Percent \\
\hline $\begin{array}{l}\text { Gender } \\
\text { Male } \\
\text { Female } \\
\text { Total }\end{array}$ & $\begin{array}{c}59 \\
\mathbf{1 4 3} \\
\mathbf{2 0 2}\end{array}$ & $\begin{array}{c}29.2 \\
\mathbf{7 0 . 8} \\
\mathbf{1 0 0 . 0}\end{array}$ \\
\hline $\begin{array}{l}\text { Age } \\
23-28 \text { years } \\
29-34 \text { years } \\
35-40 \text { years } \\
41 \text { years and above } \\
\text { Total }\end{array}$ & $\begin{array}{c}121 \\
60 \\
15 \\
6 \\
202\end{array}$ & $\begin{array}{c}\mathbf{5 9 . 9} \\
29.7 \\
7.4 \\
3.0 \\
\mathbf{1 0 0 . 0}\end{array}$ \\
\hline $\begin{array}{l}\text { Occupation } \\
\text { Student } \\
\text { Employed in a private company } \\
\text { Government/State enterprise } \\
\text { Entrepreneur } \\
\text { Housewife } \\
\text { Total }\end{array}$ & $\begin{array}{c}33 \\
\mathbf{1 4 9} \\
9 \\
10 \\
1 \\
\mathbf{2 0 2}\end{array}$ & $\begin{array}{c}16.3 \\
\mathbf{7 3 . 8} \\
4.4 \\
5.0 \\
0.5 \\
\mathbf{1 0 0 . 0}\end{array}$ \\
\hline $\begin{array}{l}\text { Monthly Income } \\
\text { Lower than USD } 330 \\
\text { USD330-660 } \\
\text { USD661-1,000 } \\
\text { USD1,001-1,330 } \\
\text { USD1,331 and above } \\
\text { Total }\end{array}$ & $\begin{array}{c}14 \\
\mathbf{6 5} \\
54 \\
33 \\
36 \\
\mathbf{2 0 2} \\
\end{array}$ & $\begin{array}{c}6.9 \\
\mathbf{3 2 . 2} \\
26.7 \\
16.4 \\
17.8 \\
\mathbf{1 0 0 . 0}\end{array}$ \\
\hline $\begin{array}{l}\text { Marital Status } \\
\text { Single } \\
\text { Married/Living Together } \\
\text { Divorced/Separated/Widowed } \\
\text { Total }\end{array}$ & $\begin{array}{c}185 \\
13 \\
4 \\
\mathbf{2 0 2}\end{array}$ & $\begin{array}{c}\mathbf{9 1 . 6} \\
6.4 \\
2.0 \\
\mathbf{1 0 0 . 0} \\
\end{array}$ \\
\hline $\begin{array}{l}\text { Type of Program } \\
\text { Regular MBA } \\
\text { Young Executive MBA } \\
\text { Executive MBA } \\
\text { Total } \\
\end{array}$ & $\begin{array}{c}39 \\
\mathbf{1 2 1} \\
42 \\
\mathbf{2 0 2}\end{array}$ & $\begin{array}{c}19.3 \\
\mathbf{5 9 . 9} \\
20.8 \\
\mathbf{1 0 0 . 0} \\
\end{array}$ \\
\hline $\begin{array}{l}\text { Major } \\
\text { Management } \\
\text { Marketing } \\
\text { Total }\end{array}$ & $\begin{array}{c}97 \\
105 \\
202\end{array}$ & $\begin{array}{c}48.0 \\
52.0 \\
\mathbf{1 0 0 . 0}\end{array}$ \\
\hline $\begin{array}{l}\text { Year of Study } \\
\text { First year } \\
\text { Second year } \\
\text { Total }\end{array}$ & $\begin{array}{c}81 \\
121 \\
202 \\
\end{array}$ & $\begin{array}{c}40.1 \\
59.9 \\
\mathbf{1 0 0 . 0}\end{array}$ \\
\hline
\end{tabular}


The descriptive analysis of satisfaction, service marketing mix, attitudinal loyalty and behavioral loyalty is shown in the following table:

Table 3: Descriptive Analysis of Satisfaction, Service Marketing Mix, Attitudinal Loyalty, and Behavioral Loyalty of MBA Students

\begin{tabular}{|c|c|c|c|}
\hline Variable & Mean & SD & Interpretation \\
\hline Satisfaction & 3.66 & 0.659 & Satisfaction level \\
\hline Service Marketing Mix & & & Level \\
\hline - Product and Service & 3.91 & 0.431 & Good \\
\hline - $\quad$ Price & 3.56 & 0.786 & Good \\
\hline - $\quad$ Place & 4.32 & 0.487 & Very Good \\
\hline - $\quad$ Promotion & 3.52 & 0.667 & Good \\
\hline - $\quad$ People & 3.92 & 0.751 & Good \\
\hline - Physical Evidence & 3.35 & 0.750 & Average \\
\hline - Process & 3.61 & 0.642 & Good \\
\hline Loyalty & & & Level \\
\hline - Attitudinal Loyalty & 3.50 & 0.420 & High \\
\hline - Behavioral Loyalty & 3.73 & 0.443 & High \\
\hline
\end{tabular}

\section{Results}

To test the first and second hypotheses, multiple regression analysis was employed in this study. The independent variable is service marketing mix, which is divided into seven dimensions: product and service, price, place, promotion, people, physical evidence, and process. The dependent variables are satisfaction, attitudinal loyalty, and behavioral loyalty. The results are shown in the table below.

Table 4: Multiple Regression Result for Student Satisfaction

\begin{tabular}{|l|c|c|c|c|}
\hline $\begin{array}{c}\text { Independent } \\
\text { Variables }\end{array}$ & $\begin{array}{c}\text { Standardized } \\
\text { Coefficients }\end{array}$ & $\mathbf{t}$ & Sig. & Adjusted R $^{\mathbf{2}}$ \\
\hline Product and Service & $\mathbf{. 4 0 2}$ & $6.450^{* *}$ & .000 & .394 \\
\hline Price & $\mathbf{. 1 3 1}$ & $2.065^{*}$ & .040 & \\
\hline Place & -.025 & -.413 & .680 & \\
\hline Promotion & -.044 & -.663 & .508 & \\
\hline People & -.011 & -.135 & .893 & \\
\hline Physical Evidence & $\mathbf{. 1 7 3}$ & $2.411^{*}$ & .017 & \\
\hline Process & $\mathbf{. 2 0 1}$ & $2.349^{*}$ & .020 & \\
\hline
\end{tabular}

Table 5: Multiple Regression Result for Student Attitudinal Loyalty

\begin{tabular}{|l|c|c|c|c|}
\hline $\begin{array}{c}\text { Independent } \\
\text { Variables }\end{array}$ & $\begin{array}{c}\text { Standardized } \\
\text { Coefficients }\end{array}$ & $\mathbf{t}$ & Sig. & Adjusted R $^{\mathbf{2}}$ \\
\hline Product and Service & $\mathbf{. 4 0 2}$ & $5.810^{*}$ & .000 & .733 \\
\hline Price & -.024 & -.342 & .680 & \\
\hline Place & -.029 & -.413 & .239 & \\
\hline Promotion & .087 & 1.182 & .461 & \\
\hline People & .069 & .739 & .659 & \\
\hline Physical Evidence & .036 & .442 & .118 & \\
\hline Process & .150 & 1.571 & & \\
\hline
\end{tabular}


Table 6: Multiple Regression Result for Student Behavioral Loyalty

\begin{tabular}{|l|c|c|c|c|}
\hline $\begin{array}{c}\text { Independent } \\
\text { Variables }\end{array}$ & $\begin{array}{c}\text { Standardized } \\
\text { Coefficients }\end{array}$ & $\mathbf{t}$ & Sig. & Adjusted R $^{\mathbf{2}}$ \\
\hline Product and Service & $\mathbf{. 3 8 6}$ & $6.248^{* *}$ & .000 & .759 \\
\hline Price & .019 & .307 & .245 & \\
\hline Place & .071 & 1.165 & .637 & \\
\hline Promotion & .031 & .472 & .536 & \\
\hline People & .051 & .620 & .342 & \\
\hline Physical Evidence & .068 & .954 & .001 & \\
\hline Process & $\mathbf{. 2 7 4}$ & $3.227 * *$ & & \\
\hline
\end{tabular}

*Statistical significance at 0.05 level. ** Statistical significance at 0.01 level

As seen in Table 4, the results indicate that product and service, process, physical evidence, and price have a strong impact on student satisfaction, which supports $\mathrm{H}_{1}$. From Tables 5 and 6 , the results show that only product and service has a strong impact on student attitudinal loyalty, whereas product and process have a strong impact on student behavioral loyalty. Both tables support $\mathrm{H}_{2}$. The results confirm several studies in the marketing literature where the service marketing mix has a strong impact on satisfaction and loyalty (Woodside and Trappey, 1992; Williams et al., 1978; Urbany et al. 2000; Magi 2003; Babin and Darden 1996; Yoo et al. 2000).

The Pearson product moment correlation coefficient was employed for testing the third hypothesis. The result is shown in the following table:

Table 7: Correlation between Satisfaction and Loyalty

\begin{tabular}{|c|c|c|c|}
\hline & \multicolumn{2}{|c|}{ Satisfaction } & Level of Correlation \\
\hline Loyalty & Pearson Correlation & Prob. & Rather Low \\
\hline Attitudinal Loyalty & $\mathbf{. 3 6 8 * *}$ & .000 & Moderate \\
\hline Behavioral Loyalty & $\mathbf{. 4 7 9} * *$ & .000 & \\
\hline
\end{tabular}

** Statistical significance at 0.01 level

As noted in Table 7, the results indicated that student satisfaction has a rather low positive relation to student attitudinal loyalty, whereas student satisfaction has a moderately positive relation to student behavioral loyalty. The result supports $\mathrm{H}_{3}$ and confirms the statement that consumer satisfaction leads to consumer loyalty.

\section{CONCLUSIONS}

According to the descriptive result, it has been found that students give the highest mean score on service marketing mix to the place aspect, followed by people, product and service, process, price, promotion, and physical evidence, respectively. The reason is that Srinakharinwirot University is located in a business area and has a campus that is convenient to access. Students can reach the university by using any of several methods of public transportation systems, such as Sky Train, boat taxi, subway, train, or bus. Furthermore, this program's curriculum satisfies student needs. In the MBA program, we offer academic instructors from several universities and wellknown businessmen to teach several of the courses. Therefore, students learn from individuals with relevant experience and are exposed to open-minded scenarios.

The results of this study confirm the preposition presented in the literature that service marketing mix has a strong impact on satisfaction and loyalty (Urbany et al. 2000; Magi 2003; Yoo et al. 2000). However, only the product and price aspect has an important impact on satisfaction, attitudinal loyalty, and behavioral loyalty. Process aspect has an impact only on satisfaction and behavioral loyalty. Physical evidence and price aspects have an impact only on satisfaction. Therefore, the product and service aspect is the most important factor in driving student satisfaction and loyalty. This result implies that the MBA program should pay attention to curriculum, instructors, and abilities of students after graduation. 


\section{MANAGERIAL IMPLICATIONS}

To build brand loyalty, the director of the MBA program should create a relevant curriculum to satisfy student demand and the instructors should come from a variety of sources and academic backgrounds to offer their experience to the students. MBA students come from varied educational backgrounds, such as engineering, the humanities, linguistics, and so on. Hence, they demand lecturers who have solid backgrounds in both academic areas and business. Most of the MBA programs in Thailand, however, focus only on the place and price aspects. The reason is that the majority of MBA students are office workers. Therefore, several MBA programs are located in business areas to help students avoid heavy traffic flows (Bangkok is one of the most congested capital cities in the world) and, additionally, offer low tuition fees to motivate the applicants. These aspects draw attention only at the beginning of an MBA program. As a result, to build brand loyalty and satisfaction, an MBA program must consider product and service along with the process aspects by offering pertinent courses to MBA students. The program curriculum should continually evolve to meet student requirements. Where curriculum development is concerned, information related to customer satisfaction and loyalty is valuable to the executive director and staff of an MBA program.

\section{LIMITATIONS AND SUGGESTIONS FOR FUTURE RESEARCH}

First, the ability to generalize the findings is limited since this study was conducted in one university only. Second, this study focused only on the student perspective, which is one limitation placed on understanding the extent of customer loyalty and satisfaction in the service industry.

\section{AUTHOR INFORMATION}

Nak Gulid is a full-time lecturer in the Department of Business Administration at the Srinakharinwirot University in Thailand. He can be contacted at the University or by sending an email to nakgulid@ gmail.com.

\section{REFERENCES}

1. Babin,B.J. and Darden, W.R. (1996). "Good and Bad Shopping Vibes: Spending and Patronage Satisfaction", Journal of Business Research, Vol. 35, p. 201-6.

2. Bhattacharya, C.B.; Fader, Peter S.; Lodish, Leonard M. and DeSarbo, Wayne S. (1996). "The Relationship between the Marketing Mix and Share of Category Requirements", Marketing Letters, Vol. 7 Issue 1, p. 5-18.

3. Cronin, J.J. Jr. and Taylor, S.A. (1992). "Measuring Service Quality: A Rexamination and Extension, Journal of Marketing, Vol. 56, p. 55-68.

4. Darian, J.C.; Tucci, L.A. and Wiman, A.R. (2001). "Perceived Salesperson Service Attributes and Retail Patronage Intention", International Journal of Retail \& Distribution Management, Vol. 29 No. 4/5, p. 205 13 .

5. Dick, A. and Basu, K. (1994). "Customer Loyalty: Toward an Integrated Conceptual Framework”, Journal of the Academy of Marketing Science, 22(2), p. 99-113.

6. Fornell, C. (1992). “A National Customer Satisfaction Barometer: The Swedish Experience”, Journal of marketing, Vol. 56, p. 6-21.

7. Graduate School Srinakharinwirot University available at www.swu.ac.th

8. Hakansson, H. and Waluszewski, A. (2005). "Developing a New Understanding of Markets: Reinterpreting the 4Ps", The Journal of Business \& Industrial Marketing, 20(2/3), 110-117.

9. Henning-Thurau, T.; Gwinner, K.P. and Gremler, D.D. (2002). "Understanding Relationship Marketing Outcomes: An Integration of Relational Benefits and Relationship Quality", Journal of Service Research, Vol. 4 No. 3, p. 230-47.

10. Homburg, C.: Koschate, N. and Hoyer, W.D. (2006). "The Role of Cognition and Affect in the Formation of Marketing, Journal of Marketing, Vol. 70, July, p. 21-31.

11. Jacoby, J. and Chestnut, W. (1978). Brand Loyalty-Measurement and Management. New York: Wiley.

12. Jacoby, J. and Kyner, D.B. (1973). "Brand Loyalty vs. Repeat Purchasing Behavior”, Journal of Marketing Research (pre-1986), 10(00001), 1. 
13. Jamal, A. (2004). "Retail Banking and Customer Behavior: A Study of Self Concept, Satisfaction and Technology Usage," International Review of Retailing, Distribution and Consumer Research, Vol. 14 No. 3, p. 357-79.

14. Kotler, Philip (2003). Marketing Management. $11^{\text {th }}$ ed. New Jersey: Prentice-Hall.

15. Magi, A.W. (2003). "Share of Wallet in Retailing: The Effects of Store Satisfaction, Loyalty Cards and Shopper Characteristics", Journal of Retailing, Vol. 79, p. 97-106.

16. Nunnally, J.C. (1978). Psychometric Theory ( $2^{\text {nd }}$ ed.) New York: McGraw-Hill.

17. Urbany, J.E.; Dickson, P.R. and Sawyer, A.G. (2000). "Insights into Cross- and Within-Store Price Search: Retailer Estimates vs. Consumer Self-Reports", Journal of Retailing, Vol. 76 No. 2, p. 243-58.

18. Williams, R.H.; Painter, J.J. and Nicholas, H.R. (1978). “A Policy-Oriented Typology of Grocery Shopper", Journal of Retailing, Vol. 54, p. 27-42.

19. Woodside, A.G. and Trappey, R.J. (1992). "Finding out Why Customers Shop at Your Store and Buy Your Brand: Automatic Cognitive Processing Models of Primary Choice", Journal of Advertising Research, Vol. 32, p. 59-78.

20. Wong, A. and Zhou, L. (2006). "Determinants and Outcomes of Relationship Quality: A Conceptual Model and Empirical Investigation", Journal of International Consumer Marketing, Vol. 18 No. 3, p. 8196.

21. Yoo, B.H.; Donthu, N. and Lee, S.H. (2000). "An Examination of Selected Marketing Mix Elements and Brand Equity", Journal of The Academy of Marketing Science, 28 (2), 195-211. 